\title{
The Practicability of Language in Business Context: A Study of Linguistic Tools in Business Discourse
}

\author{
Mohammad Husam Alhumsi \\ Saudi Electronic University, Saudi Arabia \\ E-mail: m.husamalhumsi@gmail.com
}

Received: Mar. 23, 2021

Accepted: Oct. 23, $2021 \quad$ Published: Nov. 12, 2021

doi:10.5296/elr.v7i2.18450

URL: https://doi.org/10.5296/elr.v7i2.18450

\begin{abstract}
The world witnesses a noticeable rapid growth in information technology development of society pertaining to the language of business. Research affirmed the remarkable linguistic tools in business communication lie in the form of blogs and websites of companies. Therefore, the purpose of this paper is to show how effective business context are conducted by the assistance of discourse linguistics related to business. This study adopted descriptive research approach. The findings revealed that there is a need to concentrate on the cultural meaning relating to the websites' form and content in the e-commerce context. Research also showed that there is lack of research pertaining to language role and its impact on limitation of websites and blogs. According to Forrester Research, most Chinese on-line consumers are convenient with websites involving content written in their native language. Further studies and recommendations are presented accordingly.
\end{abstract}

Keywords: business negotiation, business discourse, discourse analysis, language 


\section{Introduction}

The globe witnesses a remarkable swift increase in information technology development in society (Daniushina, 2010; Roztocki, Soja, \& Weistroffer, 2019). This noticeable growth creates significant interdisciplinary interaction of independent areas of knowledge. It also encourages innovative cross-border disciplines perspective to appear within these areas of knowledge. In the areas of language studies, there are Forensic Linguistics (Alhumsi, 2019); other possible names include Legal, or Judicial Linguistics (Gibbons, 2003), Media Linguistics (Dobrosklonskaya, 008), Political Linguistics (Zatusevski, 2001), and Ethno-linguistics (Kindell \& Lewis, 2000). In addition, Kruzel (2008) introduced Military Linguistics, Wang (2008) introduced Environment Linguistics, and Bruzzi (2006) presented Medical Linguistics. It should be noted that the term 'Business Linguistics' has been proposed by Daniushina (2010) and Danyushina (2011).

The topic of Business Linguistics, introduced by Daniushina (2010) and Danyushina (2011), is the study of language function that deals with business as well as the linguistic field of business communication. In this novel aspect, the methodology should include discourse pertaining to classical research methods, text linguistics, discourse analysis, cognitive, pragmatic and genre-style analysis, and conversation analysis. It should be noted that the terminology of Business Linguistics is still under construction. The researcher posited that this specific discipline can be constructed based on the aforementioned disciplines. Thus, according to Danyushina (2011), Business Linguistics can be defined as an area that investigates the specific language function related to business context; it also examines the language resources usage in business activities as well as studying the aspects of verbal and para-verbal business communication.

Daniushina (2010) pointed out that the beginnings of Business Linguistics as an innovative interdisciplinary area can be detected in Psycholinguistics and Sociolinguistics, Discourse studies, Cognitive and Communication Theory, Functional styles and Text linguistics, Pragmatics, Theory of organization, Management Studies. It can be also traced in practical research concerning learning and teaching Language for Specific Purposes.

Moreover, Daniushina (2010) added that Business Linguistics interacts and intersects with various related areas. For example, it interacts with Media Linguistics if one investigates the business media discourse. As for Judicial Linguistics, one may explore the discourse of contract and property law. One may examine the language of socioeconomic relations with respect to Political Linguistics. In another aspect, Daniushina (2010) believed that Business Linguistics should tackle practical and theoretical methods on teaching and learning in the field of foreign languages for business purposes, particularly international business that deals with Business English viewed as a lingua franca.

The beginning era of Business Linguistics has been predetermined by new business demands and socio-historical preconditions (Daniushina, 2010). She argued that in the 21 st century, there has been a new period in the history of society; that is a society of consumption during huge amount of information. Thus, business ideology and relations have extended in different part of the world namely China, India, Brazil and the republics of the former USSR. It is 
interesting to note that business has attained the rank of the most effective drives of social development all over the world, given that coining new areas of social thought and the increasing role in people's lives have been remarkable issue. The same researcher affirmed that Business needs some applied discipline for the sake of its verbal and communication requirements (Danyushina, 2011). Hence, the aim of this study is to show how effective business context are conducted by the assistance of discourse linguistics related to business through providing students and businessmen with the principles of successful communication, involving skills relevant to foreign languages contexts (Daniushina, 2010).

\section{Literature Review}

\subsection{Organizational Communication, Web and Blog Discourse}

It is important to consider that there were certain scholars, interested in Management Studies, Organizational Communication, and Organization Studies, use particular terms related to business interaction. For example, Angelmar and Stern (1978) introduced "bargaining communication", Johns (1986) introduced "language at work" and "language of business", "communicating at work" was introduced by Adler (1983), and Lampi (1986) introduced "language of business negotiations". Such terms were introduced within the management and organization theories framework.

With respect to communication, it is regarded as the backbone of all organizations that shape the organizational structure (Boden, 1994). It is interesting to concern that literature highlights business discourse and organizational communication (e.g., Ehlich \& Wagner, 1995; Gotti \& Gillaerts, 2005; Trosborg \& Jorgensen, 2005). It should be noted that a variety of scholars analysed the communication models of "management speak", transactional discourse, and culture of corporate discourse (Argenti, 2008; Feely \& Harzing, 2003; Greatbatch \& Clark, 2005). For example, Swales and Rogers (1995) viewed mission statement discourse as the image of corporate culture. In short, business discourse can be defined as "all about how people communicate using talk or writing in commercial organizations to get their work done" (Bargiela-Chiappini, Nickerson, \& Planken, 2007, p. 3).

In the context of websites and blogs, corporate websites and blogs of many global companies represent linguistic tools in business practices through advertising and marketing (Danyushina, 2011). For example, organized business discourse in the famous book Naked Conversations was fully demonstrated by Scoble and Izrael (2006). The same researchers confirmed that "blogs are changing the way businesses talk with customers" (p. 3). Hence, Business is concerned with the enhancement of effective communication. Communication competence has gained inseparable part of business success strategy. Klikauer (2008) argued that a strategic manager requires having the skills of communication manager.

It is worth mentioning that literature regarding oriented blogs relating to consumption supports the manner how blogging has entitled consumers to self-publication, benefitting from marketers and experiences ( $\mathrm{Lu} \&$ Stepchenkova, 2015). Marketers valued consumption-oriented blogs since they are in favor of experiences and products that correspond to the lives of consumers, letting them to accept the expressive denotation 
involved with their expertise (Zhao \& Belk, 2007).

\subsection{The Role of Language in Electronic Commerce Sites}

Jiménez-Crespo (2013) pointed out that language forms critical infrastructure to website locations due to its rigorous cultural sign of a state. On indefinite e-commerce sites on the web, Liginlal, Ahmad, Meeds and Gopinath (2017) argued that language is not only an instrument of communication, but it successfully encourages concepts for particular purposeful people. For example, people have diverse ways of thinking about varied topics; one certain e-commerce site, a man living in countryside probably has a different perspective about healthy nutrition than those who live in cities. Hence, the selection of words plays a pivotal role in the preparation of webpage content depending on meaning and effectual use of words. In a study conducted by Nielsen, Molich, Snyder and Farrell (2000), the researchers offered an overall practical research of international e-commerce websites. They also provided guidelines and instructions for designing and planning e-commerce websites on the basis of studies regarding online shoppers and their own shopping behaviors with respect to three continents. Another study found that cultural variances of users and data preferences will not be successfully addressed from one language to another through translational processes of a website (Hillier, 2003). One may claim that a number of businesses keep on their globalization tactics based on the false assumption that potential purchasers likely know English (Liginlal et al., 2017). For example, 95\% of Chinese online customers feel comfortable with internet sites involving content presented in their own language and this result has been based on Forrester Research (Widger, Evans, McGowan, \& Camus, 2009). Additionally, over three large lands of the world, DePalma, Sargent and Beninatto (2006) conducted a survey serving eight countries. Their results showed commercial offerings modified to tastes, requirements, and local languages are much more effective since customers evaluate the capability to gain data in their own language instead of doing the price process.

Given that there is a substantial increase on users using non-English Websites, commercial works effectively satisfy the need to construct multilingual websites (Liginlal et al., 2017). Hillier (2003) reported various crucial issues concerning text translation in websites. The same researcher particularly noticed the periodic disagreement regarding words meaning and terminology, especially for technical communication and business. In another study tackling 108 websites pertaining to e-commerce involving companies from several countries, Nacar and Burnaz (2011) found that large number of such websites acted inadequately in modifying the site language to surrounding cultural values and needs.

\section{Methodology}

This paper adopted descriptive research approach (Mashingaidze, 2014). This methodology was used to investigate the practicability of language in business discourse. Creswell (2002) argued that the purpose of descriptive research is not to constitute hypotheses or develop a theory. In this respect, noticeable linguistic tools in business communication represented by websites and blogs to highlight the effective business context in research papers. 


\section{Findings and Discussion}

It should be noticed that some researchers tackled the issue of business communication as well as intercultural business discourse. They analyzed multiple features of intercultural business discourse and business communication in the national languages (Beamer \& Varner, 2001). The same researchers identified intercultural communication in the global workplace. Another study conducted by Varner (2000) provided a design for the intercultural business communication theoretical model. Another researcher offered a comparison between English and Japanese business communication (Kameda, 2005). As for multicultural business, Ponchini (2004) proposed discursive strategies' meetings relating to such aspect. In the same thread, Piekkari and Zander (2005) posited a conversation model relevant to a multicultural presentation, providing information for the purpose of communication with Asian, European, and different cultures. Thus, Language is processed as an influential aspect in multinational management (Spencer-Oatey \& Xing, 2005). Also, Bargiela-Chiappini et al. (2007) presented a complex aspect of business discourse in their work entitled 'Business Discourse'. These researchers offered a revision of commendable papers in the field, representing profiles of well-known scholars in addition to the description of the methodology for investigating as well as teaching business discourse.

It is interesting to note that extensive research tackling empirical quantitative studies detecting the potential of blogs in marketing exists and it has been found on topics covering travel blogs (Bosangit, Mccabe, \& Hibbert, 2016). In addition, despite the small number of studies concerning travel blogs adopting qualitative methodology (Berger \& Greenspan, 2008; Banyai \& Glover, 2012), there are more studies on travel blogs contents used quantitative methodology (Banyai \& Havitz, 2013). The existence of large number of data structured in digital format is probably the reason behind the adoption of more quantitative research methods (Bosangit et al., 2016).

Additionally, Chen, Yen, Pornpriphet and Widjaja (2015) pointed out that information quality is considered as an additional influence of success according to a cross-cultural view. In the same thread, Pauwels (2012) noted that recent research studies propose a need to pay more attention to cultural meaning that the content and form of websites address due to the fact that researchers dedicate little focus on the language role and its impact on websites localization on the basis of records made in the Arab world in the field of e-commerce (Liginlal et al., 2017; Nacar \& Burnaz, 2011).

Due to the recent substantial increase of e-commerce, Ferraro and Brody (2015) argued that great business companies are identifying the cultural potential results of extending their works and corporations to reach the global markets. The term "Think globally but act locally" has long been regarded as crucial in order to win consumers' confidence in e-commerce business (Liginlal et al., 2017, p. 75). In addition, in order to target more audience, a website should be sufficiently modified to make it more culturally appropriate.

\section{Conclusion and Further Studies}

A considerable practical study of global websites relating to e-commerce as well as offering 
basics for designing e-commerce sites have been addressed in research (Nielsen et al., 2000). On a website tackling electronic commerce issues, the matter of language is not just a tool for communication; it significantly assists in forming ideological thoughts for intended readers. This is why websites and the blogs of multiple companies in the world have been addressed as linguistic tools when such companies made advertising and marketing it has been found that various businesses are not fully certain to get involved in global markets since they lack awareness of Web localization results as well as the need for cultural customization. It has been also found that the issue of cultural variances of users and data preferences has been argued in relation to websites translational processes. Hence, multiple critical issues concerning text translation in websites have been reported. Thus, empirical studies including text translation and transitivity analysis system on blog articles may have potential effect on gaining more data in order to linguistically understand the nature of the blog.

\section{References}

Adler, R. B., \& Elmhorst, J. M. (1992). Communicating at work: Principles and practices for business and the professions. New York: McGraw-Hill.

Alhumsi, M. H. (2019). Key aspects in relation to forensic linguistics. International Journal of Linguistics, Literature and Translation, 2(5), 83-86.

Angelmar, R., \& Stern, L. W. (1978). Development of a content analytic system for analysis of bargaining communication in marketing. Journal of Marketing Research, 15(1), 93-102. https://doi.org/10.1177/002224377801500111

Argenti, P. A. (2008). Corporate communication (5th ed.). New York, McGraw-Hill.

Banyai, M., \& Glover, T. D. (2012). Evaluating research methods on travel blogs. Journal of Travel Research, 51(3), 267-277. https://doi.org/10.1177/0047287511410323

Banyai, M., \& Havitz, M. E. (2013). Analyzing travel blogs using a realist evaluation approach. Journal of Hospitality Marketing \& Management, 22(2), 229-241. https://doi.org/10.1080/19368623.2012.680239

Bargiela-Chiappini, F., Nickerson, C., \& Planken, B. (2007). Business Discourse. Basingstoke, Palgrave, Macmillan. https://doi.org/10.1057/9780230627710

Beamer, L., \& Varner, I. I. (2001). Intercultural communication in the global workplace. New York, NY: McGraw-Hill/Irwin.

Berger, I. E., \& Greenspan, I. (2008). High (on) technology: Producing tourist identities through technologized adventure. Journal of Sport \& Tourism, 13(2), 89-114. https://doi.org/10.1080/14775080802170312

Boden, D. (1994). The business of talk. Organizations in action. London, Polity Press

Bosangit, C., McCabe, S., \& Hibbert, S. (2016, September). Discourse Analysis of Blogs: Analyzing Language to Maximize the Value of Consumption-Oriented Blogs as Data Source (pp. 522-532). In Conference on e-Business, e-Services and e-Society. Springer, Cham. 
https://doi.org/10.1007/978-3-319-45234-0_46

Bruzzi, J. F. (2006). The words count-radiology and medical linguistics. New England Journal of Medicine, 354(7), 665-667. https://doi.org/10.1056/NEJMp058262

Chen, J. V., Yen, D. C., Pornpriphet, W., \& Widjaja, A. E. (2015). E-commerce web site loyalty: A cross cultural comparison. Information Systems Frontiers, 17(6), 1-17. https://doi.org/10.1007/s10796-014-9499-0

Creswell, J. W. (2002). Educational research: Planning, conducting, and evaluating quantitative. Upper Saddle River, NJ: Prentice Hall.

Daniushina, Y. V. (2010). Business linguistics and business discourse. Calidoscópio, 8(3), 241-247. https://doi.org/10.4013/cld.2010.83.08

Danyushina, Y. V. (2011). Business Linguistics-A new interdisciplinary synergy. International Journal of Arts \& Sciences, 4(18), 177-186.

DePalma, D., Sargent, B., \& Beninatto, R. (2006). Does language matter? Can't read, won't buy. Retrieved from http://www.commonsenseadvisory.com

Dobrosklonskaya, T. G. (2008). Medialinguistics: A systematic approach to the study of the language of the media (modern English media speech). Moscow: Flinta: Nauka.

Ehlich, K., \& Wagner, J. (1995). The discourse of international negotiations. Berlin, Mouton de Gruyter. https://doi.org/10.1515/9783110881516

Feely, A., \& Harzing, A. (2003). Language management in multinational companies. Cross-Cultural Management, 10(2), 37-52. https://doi.org/10.1108/13527600310797586

Ferraro, G., \& Brody, E. K. (2015). Cultural Dimension of Global Business. New York: Routledge. https://doi.org/10.4324/9781315664415

Gibbons, J. (2003). Forensic linguistics: An introduction to language in the justice system. Wiley-Blackwell.

Gotti, M., \& Gillaerts, P. (2005). Genre variation in business letters. Bern, Peter Lang

Greatbatch, D., \& Clark, T. (2005). Management speak: Why we listen to what management gurus tell us. London/New York, Routledge. https://doi.org/10.4324/9780203087718

Hillier, M. (2003). The role of cultural context in multilingual website usability. Electronic Commerce Research and Applications, 2(1), 2-14. https://doi.org/10.1016/S1567-4223(03)00005-X

Jiménez-Crespo, M. A. (2013). Translation and web localization. NY: Routledge. https://doi.org/10.4324/9780203520208

Johns, A. M. (1986). The language of business. Annual Review of Applied Linguistics, 7, 3-17. https://doi.org/10.1017/S0267190500001616

Kameda, N. (2005). A research paradigm for international business communication. 
Corporate Communications: An International Journal, 10(2), 168-182. https://doi.org/10.1108/13563280510596970

Kindell, G. E., \& Lewis, M. P. (Eds.). (2000). Assessing ethnolinguistic vitality: Theory and practice: Selected papers from the Third International Language Assessment Conference (Vol. $3)$.

Klikauer, T. (2008). Management Communication: Communicative ethics and action. Springer. https://doi.org/10.1057/9780230583238

Kruzel, J. (2008). Official Responds to Congressional Findings on Military Linguistics. American Forces Press Service News.

Lampi, M. (1986). Linguistic components of strategy in business negotiations (Vol. 85). Helsinki School of Economics.

Liginlal, D., Ahmad, R., Meeds, R., \& Gopinath, P. (2017). Metaphorical expressions in e-commerce: A study of Arabic language websites. Journal of Global Information Technology Management, 20(2), 75-90. https://doi.org/10.1080/1097198X.2017.1321354

Lu, W., \& Stepchenkova, S. (2015). User-generated content as a research mode in tour-ism and hospitality applications: Topics, methods, and software. Journal of Hospitality Marketing \& Management, 24(2), 119-154. https://doi.org/10.1080/19368623.2014.907758

Mashingaidze, S. (2014). Descriptive Business Intelligence Analysis: Cutting Edge Strategies Asset for SMES. Is It Really Worth It? Journal of Governance and Regulation, 3(4), 70-83. https://doi.org/10.22495/jgr_v3_i4_p7

Nacar, R., \& Burnaz, S. (2011). A cultural content analysis of multinational companies' websites. Qualitative Market Research: An International Journal, 14(3), 274-288. https://doi.org/10.1108/13522751111137505

Nielsen, J., Molich, R., Snyder, C., \& Farrell, S. (2000). E-commerce user experience. Technical Report (Vol. 01: User Behavior, Key Findings and Executive Summary for the Series). Nielsen Norman Group.

Pauwels, L. (2012). A multimodal framework for analyzing websites as cultural expressions. Journal of Computer-Mediated Communication, 17(3), 247-265. https://doi.org/10.1111/j.1083-6101.2012.01572.x

Piekkari, R., \& Zander, L. (2005). Preface: Language and communication in international management. International Studies of Management \& Organization, 35(1), 3-9. https://doi.org/10.1080/00208825.2005.11043726

Ponchini, G. (2004). Discursive strategies in multicultural business meetings. Bern, Peter Lang.

Roztocki, N., Soja, P., \& Weistroffer, H. R. (2019). The role of information and communication technologies in socioeconomic development: Towards a multi-dimensional framework. Information Technology for Development, 25(2), 171-183. 
https://doi.org/10.1080/02681102.2019.1596654

Scoble, R., \& Israel, S. (2006). Naked conversations: How blogs are changing the way businesses talk with customers. John Wiley \& Sons, Inc.

Spencer-Oatey, H., \& Xing, J. (2005). Managing talk and non-talk in intercultural interactions: Insights from two Chinese-British business meetings. Multilingua, 24(1-2), 55-74. https://doi.org/10.1515/mult.24.1-2.55

Swales, J. M., \& Rogers, P. S. (1995). Discourse and the projection of corporate culture: The mission statement. Discourse \& Society, 6(2), 223-242. https://doi.org/10.1177/0957926595006002005

Trosborg, A., \& Jorgensen, P. E. (2005). Business discourse, Texts and contexts. Bern, Peter Lang.

Varner, I. I. (2000). The theoretical foundation for intercultural business communication: A conceptual model. The Journal of Business Communication, 37(1), 39-57. https://doi.org/10.1177/002194360003700102

Wang, Q. (2008). Towards the built environment linguistics. Nottingham. Doctoral Dissertation. University of Nottingham.

Widger, Z., Evans, P., McGowan, B., \& Camus, L. (2009). Translation and localization of retail web sites: Maximizing the international experience through tailored offerings. Retrieved from http://www.forrester.com

Zatusevski, E. (2001). Mass Media and Political Linguistics in the Period of Democratization of Society. In ANNUAL KOKKALIS WORKSHOP, 3.

Zhao, X., \& Belk, R. W. (2007). Live from shopping malls: Blogs and Chinese consumer desire. Advances in Consumer Research, 34, 131.

\section{Copyright Disclaimer}

Copyright reserved by the author(s).

This article is an open-access article distributed under the terms and conditions of the Creative Commons Attribution license (http://creativecommons.org/licenses/by/4.0/). 